\title{
TUTELA DOS DIREITOS NO CÓDIGO CIVIL PORTUGUÊS *
}

\author{
Prof. E. D. MONIZ DE ARAGÃO \\ (Catedrático de Direito Judiciário Civil.)
}

Sumário: 1. Explicação. 2. Código Civil de 1867. 3. Código de Processo Civil de 1939. 4. Código Civil de 1966. 5. Autonomia do Direito Processual. 6. Efeitos dessa autonomia em textos legislativos. 7. Caracterização das normas processuais. 8 . Normas formais insertas em leis materiais. 9. Pertinência do direito probatório. 10. Inclusão do direito probatório no Direito Processual. 11. Pertinência do ônus da prova. 12. Enunciação dos meios de prova. 13. Poder dispositivo em tema de prova. 14. Ônus da prova. 15. Contraprova. 16. Presunções. 17. Confissão. 18. Documentos. 19. Perícia e inspeção judicial. 20. Testemunhas.

1. A presença de um professor de Direito Processual Civil neste ciclo de estudos a propósito do nôvo Código Civil português está a exigir uma explicação, muito simples por sinal. A exemplo de outros, o Código contém normas de cunho processual sôbre as quais cumpre proceder a uma breve análise.

A inclusão de regras formais em lei material sugere uma rápida divagação em tôrno do problema em si, seja encarando-o à luz da legislação lusa, seja examinando-o em face da doutrina processual, abordada a interdependência assim entre os dois ramos do direito como entre os códigos que lhes são próprios.

2. O Código português de 1867, em sua última parte, a quarta, tratava "da ofensa dos direitos e da sua reparação", compondo-se essa parte de dois livros: um, a propósito da responsabilidade civil, e outro, "da prova dos direitos e da restituição dêles". Esse casamento da responsabilidade civil com a prova dos direitos

* Conferência pronunciada a 7 de fevereiro de 1969, a convite do Instituto de Ciências Sociais e Direito Comparado da Universidade do Paraná. 
e o modo de serem restituídos não tem razão de ser, pôsto que não são assuntos inter-relacionados em medida tal que a união se justificasse. O exemplo foi dado pelo Código Civil de Napoleão que, por ausência de parte geral, incluiu o assunto no capítulo alusivo ao direito das obrigações. Ademais, "restituição" dos direitos é fórmula prêsa às idéias então vigentes, do mais arraigado conceito civilístico de ação, que nesta enxergavam apenas o meio de restabelecer direitos violados. Falar em "prova dos direitos" também não parece muito acertado, pois é sabido, segundo o mesmo Código afirmava, que "a prova é a demonstração da verdade dos fatos alegados em juízo".(')

O primeiro livro se subdividia em dois títulos, um dos quais destinado à disciplina da prova, nesta inserida tôda a matéria do registo civil das pessoas naturais e, ainda, o "caso julgado". O outro livro cogitava "das ações", composto de quatro artigos: um, vedando a justiça de mão própria, com a rubrica "abolição da autodefesa", outro, estabelecendo o papel da lei na proteção e salvaguarda dos direitos subjetivos, um terceiro, explicando que "os juízos e as ações" são os meios através dos quais os direitos podem ser restituídos, indenizados ou assegurados" e finalmente o último, acentuando que "a organização e a jurisdição dos juízes são regulados por leis especiais" e "as regras relativas às ações pertencem ao Código de Processo".

3. Ao reformular a legislação processual em 1939, editando - Código de Processo Civil, Portugal mudou o rumo de sua antiga opinião, regulando nessa lei tôda a matéria pertinente ao direito probatório, deixando no Código Civil apenas os assuntos que the são peculiares.

Ter-se-ia a impressão de que nesse momento o legislador se bandeara em definitivo para o grupo dos que consideram apenas processuais assuntos tidos como substanciais pelo Código de 1867, impressão desfeita, porém, pelo Código atual, que nessa matéria volta a trilhar a senda anterior, dizendo a "apresentação" do texto proposto que "no subtítulo em que trata do exercício e tutela dos direitos, o projeto chama de nôvo ao Código a parte substantiva do regime de provas, introduzindo freqüentes alterações à lei processual em vigor". $\left.{ }^{2}\right)$

4. O Código de 1966 está dividido em cinco livros, dos quais - primeiro cogita da parte geral, distribuída em dois títulos: um, relativo às leis, sua interpretação e aplicação, e outro, alusivo às relações jurídicas. Enquanto o primeiro é uno, o segundo está dividido

1. Art. 2.404 .

2. Projecto de Código Civil, Imprensa Nacional de Lisboa, 1966, p. XL. 
em quatro subtítulos, o derradeiro dos quais obedece à epígrafe "do exercício e tutela dos direitos".

Compõe-se o subtítulo de dois capítulos: um, respeitante às disposições gerais, outro, à prova.

Das disposições gerais cuidam os artigos 334 a 340, versando sôbre o abuso de direito, a colisão de direitos, a ação direta, a legítima defesa, o êrro acêrca dos pressupostos do exercício dêstes dois últimos, o estado de necessidade e o consentimento do lesado.

Encartado embora no subtítulo alusivo ao exercício e tutela dos direitos e pôsto em pé de igualdade com o capítulo correspondente à prova, o tema das disposições gerais não é específico do Direito Processual, no sentido que a êste se dá nos cursos jurídicos.

Certo, pode-se dizer que é processo, extrajudiciàriamente considerado, aquêle que cogita do exercício de um direito, mesmo que pelo próprio interessado. Mas, para os efeitos a que êste ciclo de estudos visa, não é possível ir tão longe. Manter-me-ei, portanto, em limites mais modestos.

Sete são as secções por que se espraia a disciplina da prova. A primeira contém disposições gerais e as seis restantes tratam: das presunções, da confissão, dos documentos, das perícias, da inspeção judicial e das testemunhas. A secção dos documentos subdivide-se em quatro subsecções: uma com disposições gerais e as três outras tratando dos documentos, autênticos, particulares e especiais.

A inclusão no Código Civil de um capítulo alusivo a exercício e tutela dos direitos reflete idéias originadas entre os pandectistas. Basta relancear os olhos pelo índice de matérias do Direito das Pandecłas, de BERNARD WINDSCHEID, $\left({ }^{3}\right)$ para observar que o Livro II, dedicado à análise "dos direitos em geral", se compõe de quatro capítulos: um sôbre o conceito e espécie dos direitos, outro sôbre o sujeito do direito, o terceiro sôbre o nascimento, extinção e modificação dos direitos e o último sôbre o "exercício, violação e tutela dos direitos", abrangendo entre outros assuntos os que respeitam ao exercício dos direitos, à violação dos direitos, ao exercício das próprias razões, à coisa julgada e à prova. Êsses temas muito se aproximam dos que foram incluídos nas duas codificações de Portugal.

5. Durante muitos séculos o Direito Processual foi considerado capítulo do Direito Civil, cujas regras eram postas em ação através daquele.

3. Diritto delle Pandette, trad. de CARLO FADDA e PAOLO BENSA, Turim, 1902. 
Resultava, então, que o Direito Processual era tido como um dos ramos privados da dicotomia tradicional.

Estudos desenvolvidos na Alemanha no Século XIX, salientando-se a polêmica travada entre WINDSCHEID e MUTHER, $\left({ }^{4}\right)$ em tôrno do conceito da actio romana e da Klage alemã, demonstraram a pouco e pouco que o enquadramento do Direito Processual no ramo privado não tinha razão de ser. A publicização do direito processual se mostrava irretorquível, se considerado o fato de servir à atuação do Estado no exercício de uma de suas funções soberanas: a jurisdicional. Por outro lado, tinha de ser considerada, ainda, a presença obrigatória do juiz na relação processual, mostrando que o órgão do Estado é pessoa indispensável à realização do processo, o que serve a situá-lo no setor público da divisão do direito.

Firmada essa premissa foi fácil passar à comprovação da autonomia do Direito Processual, que se desprendeu do Direito Civil, assim como do Direito Comercial, passando a ter vida própria.

No desenvolvimento e demonstração dessas verdades muito contribuíram nem só juristas alemães como os italianos, em cujos países ainda proliferam as pesquisas e os estudos melhor aprofundados a seu respeito.

6. Se aparenta estar completa no plano doutrinário, essa evolução ainda se encontra muito longe de haver atingido o ápice no terreno legislativo.

Os conceitos de natureza teórica, como é compreensível, não poderiam deixar de refletir na concepção dos legisladores de cada época, de sorte que inúmeros problemas de caráter processual eram considerados como se fôssem de cunho material e incluídos nas leis denominadas substantivas, expressão que pouco representa mas continua a ter larga voga.

Ainda na atualidade depara-se em leis materiais com assuntos de índole formal. Algumas vêzes com maior, outras com menor justificativa.

Em alguns casos êsse tratamento comum deriva da necessidade de homogeneizar certos institutos, como se dá com a falência, indicada acertadamente como execução processual coletiva mas de tal modo entrelaçada com princípios e normas inerentes ao Direito Comercial que tem parecido de boa prudência regulá-la em lei única,

4. Polemica Intorno al "Actio" trad, de ERNST HEINITZ e GIOVANNI PUGLIESE, Florença, 1954. 
ao invés de distribuí-la pelos códigos processual e comercial. Outro tanto poderia ser dito a respeito da desapropriação.

Casos há que encontram explicação distinta. Em países de competência legislativa múltipla, como aconteceu entre nós de 1891 a 1934, a legislação material está reservada a um órgão ao passo que as leis formais podem competir a outro, eventualmente a vários outros. Nesta situação sucede, às vêzes, que a política legislativa recomenda a inclusão em leis de direito material de princípios que são processuais, a fim de evitar-lhes disciplinação díspar em regras processuais variadas quanto à procedência. Esta razão foi dada por CLÓVIS BEVILAQUA, autor do Código Civil, para neste incluir diversas disposições pertinentes ao processo entre as normas fadadas à proteção possessória. A preocupação de manter uniforme a salvaguarda da posse foi o motivo dessa atitude. $\left({ }^{5}\right)$

Ainda um tipo de exemplo pode ser indicado, quando se está em face de certa providência de aspecto material cujo êxito depende de complementação que deve ser fornecida pelo direito formal. Recentemente, o Anteprojeto de Código Penal elaborado por NELSON HUNGRIA, disciplinando o delito de lesões corporais provocadas por acidente de automóvel, dispõe que o causador das lesões não será prêso em flagrante se prestar imediato socorro à vítima. ( $\left.{ }^{6}\right)$ Embora seja nitidamente processual o problema de ser alguém prêso em flagrante delito, o resultado a que o direito material visa (que é diminuir os casos de acidentados abandonados à própria sorte na via pública porque o condutor do veículo tema ser prêso) só pode ser atingido se afastado o risco da prisão em flagrante. Logo, a solução processual está ligada tão umbelicalmente ao problema material que o autor do anteprojeto entendeu de indicá-la desde logo. A medida de política criminal depende, para ter efeito, de uma fórmula processual que o legislador do direito material resolveu adotar também.

7. Por outro lado, a inclusão de certa norma em determinada lei nem the fixa a natureza nem pode, de modo algum, alterar-lhe a substância.

5. Eis a lição de BEVILAQUA: "Alguns Códigos Civis não se ocupam dos interditos posses"sórios, por ser matéria processual; mas justifica-se o sistema contrário, pela íntima liga"ção existente entre a posse e a sua proteção; e porque mais avulta nas relaçõees jurídi"cas a defesa da posse do que o próprio fato em que ela consiste. Se, no Brasil, se "entregasse aos Códigos processuais a matéria dos interditos, teríamos, dispersando os "elementos da teoria possessória, tornado muito precária a sua firmeza" (Comentários ao "Código Civil, n. 2 ao art. 499).

6. Art. 140, par. ún.: "Se o agente abstém-se de fugir e, na medida que as circunstâncias o "permitirem, presta ou providencia para que seja prestado socorro à vítima, fica isento "de prisão em flagrante". A regra ingressou no nôvo Código Penal (Decreto-Lei n. 1.004, de 21 de outubro de 1969), art. 291, par. único. 
Por mais que colocado no código civil, o preceito é processual e segue sendo-o da mesma maneira que a inserção de norma de cunho civil em um código penal não significa a sua transmudação.

A norma legal se caracteriza pelo conteúdo e não pela localização.

Se o dispositivo regula a atuação da lei e visa a reger relações jurídicas de modo a propiciar a imposição da sentença, é e será sempre processual, não importa o repositório em que esteja situado.

8. Regras há, porém, que embora destinadas a proporcionar a solução judiciária para relações jurídicas ora são ditas de natureza processual ora de natureza material, ainda não se tendo definido satisfatòriamente as controvérsias doutrinárias a seu respeito.

Sôbre estas é que, o mais das vêzes, recai tratamento legislativo em codificação material, sem que a maior crítica, no fundo, caiba ao legislador, porquanto não the incumbe fazer doutrina, ou tomar parte em disputas, mas fornecer segurança e tranqüilidade ao comércio jurídico.

Entre os institutos a cujo respeito ocorre tal dissídio figura o direito probatório.

Nesse setor é que são encontradas disposições de cunho processual no Código Civil português.

9. Há um grupo de autores a lecionar que as normas alusivas à prova interessam assim ao direito material como ao processual. Dessa afirmação extraem a conseqüência de que o assunto deve ser disciplinado em parte pelo primeiro e em parte pelo segundo dêsses ramos do Direito. Ao primeiro deverão competir as regras atinentes à regulamentação e admissibilidade dos meios de prova bem como ao ônus da prova. Ao segundo deverão ficar entregues os problemas alusivos à proposição, admissão, produção e assunção das provas, vale dizer o procedimento probatório. Há quem defenda posições intermédias, o que é muito comum, fazendo concessões maiores ou menores a um dos ramos, consoante entenda que certo assunto probatório é mais ligado a êste ou àquele.

Outros, porém, partindo do princípio de que a prova se destina a convencer o juiz da veracidade dos fatos da causa, a fim de capacitá-lo a proferir decisão, afirmam que tôda a matéria respeitante às provas deve estar incluída no ramo apenas processual, razão não existindo para a partilha preconizada pelos primeiros. É o que lecionava em Portugal o Professor JOSÉ ALBERTO DOS REIS. $\left({ }^{7}\right)$

7. Código de Processo Civil Anotado, Coimbra, 1950, vol. III, ps. 240-241. 
Trata-se de uma questão já sovada, esta da pertinência do direito probatório às leis materiais ou processuais e, contudo, as opiniões a seu respeito permanecem divididas.

Dentre os que sustentam tese divergentes, a resenha dos argumentos de dois exímios processualistas italianos poderá esclarecer o estágio em que se encontra o debate.

Em artigo intitulado Tutela dos Direitos, divulgado em 1943, $\left(^{8}\right)$ CARNELUTTI abordou especificamente o problema da pertinência de certos assuntos a um dos códigos, civil ou processual civil, defendendo a solução italiana de 1942, pela qual, entre outros, o direito probatório foi mantido no primeiro, a igual do que já ocorrera em 1865, e a despeito de muitas opiniões adversas, inclusive a que êle próprio emitira em escritos anteriores.

Eis o que afirmou o notável jurisconsulto:

"Ao contrário do que seria possível prever em face dos ante"cedentes, nesse ponto não houve dificuldades entre os expertos in"cumbidos de projetar o Código Civil e o Código de Processo Civil. "Os cultores do processo, no momento em que a sua ciência se cons"tituía na Itália, haviam pretendido que reingressassem em seus do"mínios êsses institutos. Seguindo o insigne MATTIROLO, CHIOVEN"DA incluiu nos Princípios e mais tarde nas Instituições a teoria da "coisa julgada e a das provas; também eu, assim nas Lições e no "Sistema como ao redigir um projeto de código de processo civil, "segui esssa orientação. Mas à medida que, refletindo sôbre a rela"ção entre o direito material e o direito processual, meu pensamento "foi amadurecendo e adquirindo equilíbrio, persuadi-me de que em"bora sirvam ao processo, as provas e os bens precedem-no e, por "outra parte, a coisa julgada e o resultado do processo executivo, "conquanto se formem no processo, sucedem-no, razão por que ma"nifestei a opinião que REDENTI e CALAMANDREI compartilharam, de "que o Código de Processo Civil deveria renunciar à pretensão de "conter êsses institutos. A regulamentação dessa matéria permaneceu "no Código Civil sem disputas".

Em trabalho publicado em 1948, $\left({ }^{9}\right)$ LIEBMAN opõe-se à opinião expendida por CARNELUTTI, desenvolvendo cerrada crítica à inserção de normas processuais no Código Civil.

8. Rivista di Diritto Processuale Civile, v. 20, p. 3.

9. Rivista cit., 2.a série, v. 3, p. 154, ou Problemi de Processo Civile, p. 155 . Em artigo publicado na mesma Rivisła, o próprio LIEBMAN noticia a evolução do reexame a que - tema vem sendo submetido ùltimamente por parte de DENTI, CONSO e CAPPELLETTI (Questioni Vecchie e Nuove in Tema di Qualificazione delle Norme sulle Prove, Rivista, 2. a série v. 24, p. 353). 
De início afirma que "por certo o legislador não ignorava a "opinião que se consolidara na doutrina, tanto assim que sentiu a "necessidade de justificar a decisão de manter "a tradicional inserção "no Código Civil de certas regras aparentemente formais" (Exposição "de Motivos ao Código de Processo Civil, n. 6)".

Referindo-se à afirmativa de CARNELUTTI, de que as provas antecedem ao processo, pelo que seriam de natureza substancial e não processual, diz que se trata de fórmula simplista, um pouco brutal.

Para concluir que " na verdade se trata de instituto essencial à autonomia científica do Direito Processual", tece agudas considerações calcadas na finalidade do processo e anota um aspecto histórico de grande interêsse, o que impõe reproduzir-lhe as palavras:

"A história e o direito comparado oferecem o apoio de um "pensamento maduro, consolidado no curso de uma longa tradição "ainda hoje dominante no mundo. O Direito Comum incluía, de fato, "no Direito Processual a doutrina das ações, as provas, a coisa jul"gada e os atos de expropriação, o que é tanto mais notável quanto "êsses institutos eram estudados sob o aspecto privatístico com que, "à época, era habitual considerar o processo, e teria sido tanto mais "fácil, porisso, incluí-los no sistema do Direito Civil. Seguem-lhe o "exemplo os Direitos modernos que provêm diretamente do Direito "Comum, ou sejam, os dos países de língua alemã, dos ibéricos e "dos sul-americanos. No mesmo rumo segue o Direito Anglo-ameri"cano, que distingue claramente as figuras do direito e do remédio e "considera como pertencentes ao processo tanto a matéria probatória "quanto a autoridade da coisa julgada. Faz exceção apenas o Direito "Francês. Mas em sua história encontra-se justamente a origem dessa "anomalia, que consiste em regular no corpo das leis processuais tão "só a forma do procedimento. Aconteceu, de fato, que as ordenanças "reais que tão a fundo renovaram o processo civil nos séculos XV e XVII "proveram apenas à simplificação e unificação do procedimento das "várias regiões do reino de França, retocando ora um ora outro "dos vários institutos que na prática apresentavam imperfeições, sem, "no entanto, pretender disciplinar todo o processo e por isso sem alte"rar as figuras das ações e aquelas que se podem chamar as teorias "gerais do processo, que continuavam a ser objeto de elaboração "doutrinária. O Código de Procedimento Civil, refundindo e redi"gindo uniformemente as numerosas reformas introduzidas pelas or"denanças, limitou-se, depois, a regulamentar a parte puramente for"mal do processo, enquanto foram incluídas no Código tôdas as "demais matérias, não tanto porque os autores dos códigos as consi"derassem, conscientemente, como parte do direito material, mas 
"apenas porque as ordenanças não se tinham ocupado delas. Muito "provàvelmente é esta a origem histórica da suposta "tradição" que "o legislador italiano e a doutrina hodierna crêem poder invocar "†ão insistentemente e, parece lícito afirmá-lo, com tão pouco funda"mento. A imitação da legislação francesa representou, ao contrário, "uma verdadeira ruptura na continuidade histórica e na evolução dos "nossos institutos judiciários. Cumpre ao intérprete de hoje, portanto, "não cair no mesmo êrro e recolocar no sistema do Direito Processual "tôdas as normas que lhe pertencem, mesmo que inseridas no Có"digo Civil".

10. Sem dúvida parece mais acertada a opinião dos que, partindo do princípio de que as provas se destinam a convencer o juiz da veracidade dos fatos do processo, a fim de habilitarem-no a decidir, afirmam que o assunto integra o Direito Processual.

A anotação de CARNELUTTI ("o juiz tem em regra necessidade de provas; mas as próprias partes também a podem ter"), $\left({ }^{\prime}{ }^{\circ}\right)$ não se afigura capaz de conduzir a resultado algum. É certo que as partes podem ter necessidade das provas. Mas, e daí? Não terão as partes, por acaso, necessidade do próprio processo? Serve êsse argumento a incluí-lo no Direito Privado? (' $\left.{ }^{1}\right)$ Se se levar em conta tão só a necessidade que os particulares possam ter de algum instituto como chave para definição de sua pertinência ao Direito Civil, então êste passa a ser o único ramo do Direito, passa a ser "o" Direito. A exposição que precede o projeto de Código Civil português até certo ponto endossaria essa opinião, pois nela se justifica a existência e necessidade de uma parte geral no Código Civil a bem de tratar dos "problemas capitais do direito objetivo, comuns aos diversos ramos do Direito, quer por uma espécie de tradição legislativa criada nos diferentes países, quer pela importância singular que o Código Civil reveste no concêrto das demais codificações". $\left({ }^{12}\right)$

Afirma-se também que a prova do ato jurídico está tão ìntimamente entrelaçada com êle que o direito material deve regular a ambos. Os interessados no comércio jurídico, ao praticarem determinado ato, teriam em vista, junto a outras razões, a segurança que decorre de poderem demonstrá-lo por um específico meio de prova e êste deve ficar-lhe germanado.

Mas a prova, em tal caso, é nada mais nada menos que um problema de forma do ato jurídico e a forma deve ser considerada

10. Teoria Geral do Direito, trad. de ARMENIO AMADO, Coimbra, 1942, p. 492.

11. A observação é de LIEBMAN, no artigo de 1948.

12. Projecto, ob. cit., p. $X X X \mid X$. 
sob dois aspectos distintos e inconfundíveis: um que a torna integrante do próprio ato (como ocorre no art. 82 do Código Civil brasileiro: "a validade do ato jurídico requer agente capaz, objeto lícito e forma prescrita ou não defesa em lei $\left.{ }^{\prime \prime}\right)$, caso em que a lei material deve tratá-lo inteiramente, e outro, diverso, que se prende à simples comprovação dos fatos, caso em que ao Direito Processual compete discipliná-lo.

No primeiro dêles, o respeito à exigência formal é condição da própria existência do ato e não apenas de sua comprovação, embora por via reflexa o requisito formal tenha implicações de natureza probatória, já que não será possível tomar em consideração a tentativa de demonstrar um ato que não se apresente revestido da forma substancial prevista na lei. $\left({ }^{13}\right)$

Chega-se assim à conclusão de que há formas ad substantiam ao lado de formas ad probationem, aquelas pertinindo ao direito material e estas ao direito formal, mas não há razão para trasladar àquele assuntos que são nìtidamente dêste.

11. Em desdobramento muito natural dessa polêmica, trava-se outra a propósito da pertinência do ônus da prova ao Direito Material ou ao Direito Processual. Pela importância de que se reveste o tema, considerado a espinha dorsal do processo, $\left({ }^{14}\right)$ cumpre dedicar-lhe algumas palavras.

Várias correntes estão formadas, disputando a primazia.

Uma, dos que o situam exclusivamente no Direito Privado, inserindo no Código Civil normas fadadas a discipliná-lo. Outra, dos que o encartam exclusivamente no Direito Processual.

Duas opiniões procuram fugir a êsse binômio: a do pequeno grupo dos que o inserem no assim chamado Direito Judicial Material (Małerielles Justizrecht) e a dos que afirmam que 0 assunto não se subordina apenas ao Direito Privado, ou ao Direito Processual, tampouco ao Direito Judicial Material porquanto integra, simultâneamente, todos os ramos do Direito. A êstes se afigura que sendo a lide enraízada em um determinado setor nêle também radicará o ônus da prova; estará ora no Direito Público, ora no Privado, ora

13. LIEBMAN, nota à 2.a ed. bras. das Instituições de CHIOVENDA, trad. de J. GUIMARÃES MENEGALE, S. Paulo, 1965, v. III p. 93.

14. A afirmativa é de ROSENBERG: "Die Bedeutung der Normen über die Verteilung der Behauptungslast und der Beweislast ist sehr gross; man hat sie mit Recht "das Rückgrat des Zivilprozesses" gennant" (Lehrbuch, 9.a ed., Berlim, 1961, p. 559). Informa o autor que a autoria da observação pertence a HAMM (v. ROSENBERG, La Carga de la Prueba trad. de ERNESTO KROTOSHIN, Buenos Aires, 1956, p. 55, nota n. 4). 
será assunto para o Direito Material, ora para o Direito Processual, conforme o conflito de interêsses a ser composto repouse em algum dêsses ramos do Direito. $\left({ }^{15}\right)$

Mas a não participar do Direito Processual, nenhuma dessas fórmulas parece solucionar o problema, pôsto que o ônus da prova teria de situar-se na teoria geral do direito, dado que não é muito viável afirmar que participe de todos os ramos e, por conseguinte, deva ser por todos regulado. Se integrado na teoria geral do direito, por outro lado, em qual das diversas codificações deveria estar, para tratamento legislativo, salvo que existente uma lei especial, ou código, para tal fim?

Se se tiver que a correta localização do tema, como tem parecido ao legislador português, deve ser no Código Civil, como resolver o problema referente às decisões que hajam de aplicar tão só o Direito Processual? E os casos de Direito Administrativo? E todos, enfim, que não sejam originados de normas civis? Ou se teria de atribuir ao Código Civil a característica de supercódigo, cujas regras pairam acima de tôdas as demais leis, consoante sustenta a exposição de motivos portuguêsa?

Essas indagações parecem ficar sem resposta, salvo que se conceda ser o assunto processual, pôsto que disciplina a conduta do juiz ao concluir que a prova colhida se mostra insuficiente para convencê-lo. Neste caso, de não estarem provados os fatos, é que o magistrado, através da aplicação dos preceitos alusivos ao ônus da prova, pronunciará decisão favorável à parte não-onerada e desfavorável à parte que tinha o ônus de provar mas não o fêz, sofrendo as conseqüências de sua inércia. Tal resultado está bem expresso no Código de Processo Civil Português, revisto em 1967, cujo art. 516 afirma que "a dúvida sôbre a realidade dum fato e sôbre a repartição do ônus da prova resolve-se contra a parte a quem o fato aproveite".

12. Outro tema sujeito a disputas é o da indicação dos meios de prova.

Para üns essa enumeração é taxativa, enquanto outros a têm na conta de tão só exemplificativa.

$\mathrm{Na}$ medida em que se reconheça pertencerem as provas ao direito material, o debate se acende, pois neste caso a lei processual teria caráter meramente regulamentar, não podendo dispor a respeeito

15. ROSENBERG: "las normas relativas a la carga de la prueba pertenecen al mismo sector de derecho que el precepto jurídico cuyos presupuestos deben resultar de los hechos litigiosos" (La Carga de la Prueba, ob. cit., p. 73). 
dos meios de prova caso a indicação seja considerada taxativa, o que não ocorreria, porém, se fôsse encarada como enunciação apenas exemplificativa, ficando livre à lei processual complementá-la por via direta ou oblíqua.

Em prol da primeira opinião tem sido dito que a indicação dos meios de prova, feita genèricamente como costuma sê-lo, permite que, dentro da elasticidade resultante da menção ao gênero, possam ser incluídas novas espécies acaso surgidas. Autores há que afirmam ser possível adotar todos os meios de prova que a ciência moderna oferece, mesmo quando taxativa a enumeração legal, se se tiver em vista que no gênero prova documental é válida a inserção de modernas espécies, ignoradas do legislador, assim como no gênero prova pericial cabem tôdas as conquistas da técnica atual, raciocínio aplicável aos demais meios. $\left({ }^{16}\right)$

Mas, se se deve ter como acertada a opinião dos que defendem a enunciação em numerus clausus porque contrabalançada pela cautela do legislador, que põe no texto da lei fórmulas suficientemente amplas para serem capazes de abrigar todo e qualquer meio de prova que o futuro venha a revelar, então é de perguntar-se: por que dizer taxativa a enumeração? A ter-se como válido qualquer meio de prova, desde que aparentado do gênero que a lei aponta qual o sentido de fazer uma tal enunciação, com ares de gazua, que de limitativa só tem a aparência externa, mas procura, no fundo, ser apenas exemplificativa?

Os defensores dessa opinião mais parecem seus críticos. Ao invés de justificarem sua concepção doutrinária limitam-se a explicá-la por uma forma que busca relevar-lhe os inconvenientes, que no íntimo admitem, tanto assim que por êsse caminho, acima rememorado, logram escapar à apreciação desfavorável de seus opositores.

Outros combatem a tese da indicação taxativa, asseverando que não se pode cercear a capacidade de investigação processual aos meios de prova que estavam ao alcance do conhecimento científico do legislador de uma certa época. O progresso do direito, no que tange à solução judicial dos conflitos de interêsses, não pode andar divorciado do avanço das ciências, $\left({ }^{17}\right)$ corrente que contava com 0 apoio de LUIZ DA CUNHA GONÇALVES, $\left({ }^{18}\right)$ o qual defendia "o caráter exemplificativo do art. $2.407^{\prime \prime}$ do Código de 1867, a despeito

\footnotetext{
16. v. LOPES DA COSTA, Direito Processual Civil Brasileiro, 1.a ed., Konfino, Rio, 1947, v. II, p. 238.

17. EDUARDO COUTURE, Fundamentos del Derecho Procesal Civil, 3.a ed., Buenos Aires, 1958 , p. 262.

18. Trałado de Direito Civil, 2.a ed., São Paulo v. XII, t. II, p. 779.
} 
da afirmação que êste fazia $\left({ }^{19}\right)$ de que os meios de prova indicados seriam os únicos admitidos.

Ao inverso do que se dera em 1867, o Código de 1966 não contém uma disposição que, ao anunciar os meios de prova, diga serem os únicos admissíveis.

Mas essa omissão não autoriza concluir que se tenha inclinado pelo caráter exemplificativo, porquanto outra disposição, aparentemente desligada dessa polêmica, retrata a corrente seguida pela lei.

Do art. 345 do Código Civil, e empregando as palavras de seu próprio texto, extrai-se esta afirmação: "é nula a convenção que excluir algum meio legal de prova ou admitir um meio de prova diverso dos legais, quando: (a) se trate de direito indisponível, (b) torne excessivamente difícil a uma das partes o exercício do direito, (c) as determinações legais quanto à prova tiverem por fundamento razões de ordem pública".

Desta sorte, salvo o dispositivo acima, podem as partes assim excluir um meio de prova previsto em lei, como admitir um que nela não esteja incluído.

Mas ao juiz não será permitido, por sua iniciativa, tomar em consideração meios de prova não indicados pela lei, dado que sòmente às partes, e com diversas restrições, ficou livre a possibilidade de agir nesse sentido.

Adotou o Código, portanto, uma posição eclética.

13. Assunto que também aparenta preocupar o legislador português é o que respeita ao poder dispositivo das partes em relação ao direito probatório. O Código disciplina em regra específica as "convenções sôbre as provas", formulando uma distinção entre os direitos disponíveis e indisponíveis. Quanto a êstes nenhum contrato é lícito. Consentidos serão, porém, no que concerne àqueles, embora a liberdade não seja total, pois ficam proibidos sempre que possam implicar em "tornar excessivamente difícil a uma das partes o exercício de um direito", ou, ainda, "se as determinações legais quanto à prova tiverem por fundamento razões de ordem pública".

Esta última observação afigura-se capaz de privar de qualquer significado a liberdade de convenção, mesmo quanto a direitos disponíveis, pois se a prova tem por fim convencer o juiz da realidade dos fatos, a bem de outorgar a tutela jurisdicional com que o. Estado

19. "Os únicos meios de prova admitidos por êste Código são..." (art. 2.407, caput). 
dirime o conflito de interêsses e faz atuar a lei, segue-se que tôda determinação legal quanto à prova sempre se fundamenta em razões de ordem pública.

Tem sido dito e repetido, com sobra de motivos, que o primeiro interessado na solução de quaisquer litígios é o próprio Estado $\left({ }^{20}\right)$ e que o papel das partes, submetendo-lhe a demanda, é apenas de servir de veículo à prática da função jurisdicional.

A intervenção do Estado, por outro lado, ou é compulsória, como se dá com os direitos indisponíveis, a cujo respeito é subtraído aos interessados o poder de autocomposição (anulação de casamento, por exemplo), ou substitutiva, como se dá com os direitos disponíveis a cujo respeito, porém, não tenham logrado uma autocomposição (cobrança de dívida, por exemplo). No primeiro exemplo é fora de dúvida que uma razão de ordem pública fundamenta as determinações legais quanto à prova da ocorrência de fatos que autorizem a anulação do casamento. Mas no segundo exemplo também ocorre exatamente o mesmo, no que tange à comprovação dos fatos que permitam a prolação de sentença que condene ou não ao pagamento da dívida. Privada é apenas a relação de direito material de que se origine o litígio. A relação processual que se forma para resolvê-lo é sempre pública e apenas pública. A necessidade de compor os conflitos de interêsse, fazendo valer o ordenamento jurídico pena de instalar-se o caos, é sempre, também, de ordem pública. À primeira vista, portanto, a parte final do dispositivo parece frustrar os efeitos das anteriores.

Mas é preciso ter em conta que a lei deve entender-se de modo a não conter palavras vãs ou soluções inexequiíveis, $\left({ }^{21}\right)$ e sendo assim a proibição deve ser tida como endereçada a casos em que a forma é da essência do ato, bem como alcança a relação material sôbre que versa o processo e não a relação processual em si. Conectada à relação de direito material em que se verificou o conflito de interêsses, a regra do Código é compreensível e adequada.

Por outro lado, o fato de as partes poderem contratar em tôrno dos meios probatórios ou, eventualmente, do ônus da prova, o que tem conseqüências no plano do Direito Internacional Privado, com o que parecem tão preocupados os civilistas que tratam do assunto, não assume tamanha importância se se recordar que os interessados, mediante a transação, podem afastar a própria solução jurisdicional.

20. WOlfGang bernhardt, O Domínio das Partes no Processo Civil, in Processo Oral, Coletânea da Revista Forense, p. 182. ROSENBERG, Lehrbuch, ob. cit., ps. 2/3. CARNELUTTI, Sistema del Diritto Processuale Civile, Milão, 1936, 1/215-216.

21. COELHO DA ROCHA, Direito Civil Português, Coimbra, 1852, t. 1, p. 25. 
Ainda nas ações em que a relação de direito material envolva direito indisponível há uma certa margem para a transação, nem só quando se trate de efeitos patrimoniais (como se dá na avença em tôrno do quantum dos alimentos reclamados, por exemplo), como na confissão que implique em reconhecer a inverdade dos fatos alegados como suporte para a anulação de casamento, ou, por último, a conciliação que ponha têrmo à ação de desquite a qual, no Direito Brasileiro, ainda abrange uma forma de transação que transmude em amigável a ação de desquite litigioso. $\left({ }^{22}\right)$

14. Vencido o comentário de alguns princípios, em geral, e passando ao de certas soluções, em particular, cumpre fazer breve análise do tratamento legislativo dispensado a determinados problemas em matéria probatória.

De início, o ônus da prova.

O legislador de 1867 adotara uma posição que parece hoje inaceitável, dispondo que "a obrigação de provar incumbe àquele que alega o fato; exceto se tiver em seu favor alguma presunção de direito" (art. 2.405). Na realidade o ônus da prova não pode ser limitado pela autoria das alegações das partes. O Código de Processo Civil de 1939 enfrentou o tema, com o que pareceria que o legislador português passara a enfileirar-se entre os que o incluem no Direito Processual. Em seu art. 519, a lei prescreveu que "incumbe ao autor fazer a prova dos fatos, positivos ou negativos, que servem de fundamento à ação; incumbe ao réu fazer a prova dos fatos, positivos ou negativos, que servem de fundamento à exceção". A disciplina é incomparàvelmente melhor, revelando atualização do conceito anterior às tendências doutrinárias contemporâneas. Na revisão a que o Código de Processo Civil foi submetido em 1961, o texto passou a ter esta redação: "incumbe ao autor fazer a prova dos fatos, positivos ou negativos, que sejam constitutivos de seu direito; incumbe ao réu fazer a prova dos fatos, positivos ou negativos, que sirvam de causa impeditiva, modificativa ou extintiva do direito do autor" (art. 515).

O Código Civil atual (art. 342) sintetizou a redação, nêle se lendo que "àquele que invocar um direito cabe fazer a prova dos fatos constitutivos do direito alegado. A prova dos fatos impeditivos, modificativos ou extintivos do direito invocado compete àquele contra quem a invocação é feita".

22. A transação, conciliação ou confissão só não podem valer nos casos em que, por seu intermédio, se procure um resultado apto a contrariar a indisponibilidade do direito. Na medida, porém, em que sirvam a conservar a indisponibilidade, com $\circ$ que a finalidade da lei é atingida plenamente, nenhuma razão existe para impedir-lhes o emprêgo. 
Esta regulamentação é familiar aos juristas brasileiros por ser a mesma, substancialmente, adotada pelo Código de Processo Civil (art. 209 e $\S \S$ ) e mantida no Anteprojeto do Professor ALFREDO BUZAID (art. 362).

Ainda nas disposições gerais do capítulo atinente às provas, o Código dispõe sôbre alguns casos específicos, como o do ônus da prova nas ações meramente declaratórias negativas (art. 343), cuja decisão aproveita sempre a um dos litigantes em proporção maior do que poderia dar-se em outras ações, nas quais a sentença que conclui por sua improcedência cinge-se a declarar que o autor não tem razão, nem sempre valendo ao réu na mesma medida em que, certamente, aproveitaria ao autor julgamento que concluísse pela procedência da ação.

No art. 344 estão previstos dois casos de inversão do ônus da prova. Um dêles reproduz o princípio que figurava no art. 2.517 do Código de 1867, cogitando dos casos em que ocorre uma presunção legal ou há dispensa, ou liberação do ônus da prova, bem assim convenção das partes. O outro inverte-o a título de sancionar a parte que "tiver culposamente tornado impossível a prova ao onerado".

Das convenções sôbre o ônus da prova (art. 345,1), assunto sôbre que já ficou feita uma referência mais detalhada linhas atrás, caso seria de dizer, agora, que o Anteprojeto do Professor ALFREDO BUZAID propõe regulamentação similar, não tocando, porém, no problema das razões de ordem pública, que o tornam inviável, as quais ensejaram a breve crítica acima exposta. Ambos, o Código português e o Anteprojeto brasileiro, inspiraram-se no art. 2.697 do Código Civil italiano de 1942: "Sono nulli i patti con i quali è invertito ovvero è modificało l'onere della prova, quando si trata di diritti di cui le parti non possono disporre o quando l'inverzione o la modificazione ha per effeto di rendere eccessivamente difficile l'esercizio del diritto".

15. Discrimina o Código, também, a contraprova (art. 346) através da qual é possível pôr em dúvida, e com isso tirar proveito, a prova produzida por aquêle sôbre quem recai o ônus respectivo, e "o modo de contrariar a prova legal plena" (art. 347), pela demonstração de "não ser verdadeiro o facto que dela fôr objecto", em disposições que se revelam dispensáveis, pôsto que de sua ausência não surgiria obstáculo a que o mesmo resultado fôsse alcançado.

Em têrmos coincidentes com os do art. 212 do Código de Processo Civil brasileiro, a lei portuguêsa (art. 348) trata do problema da prova do direito consuetudinário, local ou estrangeiro. No fundo 
esta regra é a mesma que figurara no art. 2.406 do Código de 1867, e no Código de Processo Civil de 1939 (art. 519, passando a 517 na revisão de 1961).

16. Não cabe no âmbito dêste ciclo de palestras proceder a um exame das disposições do Código, pois o seu objetivo é apontar-lhe os princípios e inovações.

Por isso a única coisa a dizer das presunções (art. 349/351), colocadas logo após as disposições gerais sôbre a prova, é que a lei reproduz quase literalmente o texto de 1867 (arts. 2.516/2.519).

17. No que tange à confissão pode ser dito pràticamente o mesmo, tão poucas as alterações.

Cumpre analisar, porém, que o Código de Processo Civil de 1939 a disciplinou, inclusive revogando alguns dispositivos do Código Civil de 1867 por tê-los regulado inteiramente.

Nesse particular vale a pena pôr em relêvo a evolução do conceito de confissão.

O legislador de 1867 definira-a "o reconhecimento expresso, que a parte faz, do direito da parte contrária, ou da verdade do fato por esta alegado" (art. 2.408), englobando duas coisas distintas: a confissão e o reconhecimento do direito. $\left({ }^{23}\right)$ Em crítica que lhe endereçou, CUNHA GONÇALVES $\left({ }^{24}\right)$ salientou o êrro, que foi admitido por ALBERTO DOS REIS, $\left({ }^{25}\right)$ além de tecer outros comentários que o notável processualista em parte refutou.

O codificador processual de 1939 alterou a noção para esta: "reconhecimento que a parte faz do direito da parte contrária, ou da verdade do fato por esta alegado". Permaneceu, como se vê, a razão da crítica acima, pois continuaram reunidos o reconhecimento e a confissão.

Na reforma a que foi submetido em 1961, o Código de Processo Civil restringiu-se à confissão, abstraindo do reconhecimento: "declaração de ciência pela qual uma pessoa reconhece a realidade dum fato que the é desfavorável". Esta conceituação reproduz o ensinamento do Prof. MANUEL DE ANDRADE, referido por ALBERTO DOS REIS, nela perdurando, contudo, uma imperfeição que atrai a

23. Vide: LIEBMAN, Sul Riconoscimento della Domanda, in Problemi, ob. cit. p. 177, e MOACYR LÔBO DA COSTA, Confissão e Reconhecimento do Pedido, in Revista da Faculdade de Direito da Universidade de São Paulo, ano XLII, fasc. II, p. 167. DIAS FERREIRA, Código Civil Porługuês Anołado, 2.a ed., Coimbra, 1905, v. IV, p. 313.

24. Tratado, ob. cit., XIII-2/785.

25. Cod. de Proc. Civil Anotado, ob. cit., IV/63. 
crítica, porquanto não ficou dito que a confissão versa sôbre fato cuja admissão implica em prejuízo ao confitente, o que constava da noção do Prof. ANDRADE mas não figurou na lei. Por outro lado, não é axiomática em doutrina a opinião dos que apontam como declaração de ciência a natureza jurídica da confissão, fato também destacado por ALBERTO DOS REIS e CUNHA GONÇALVES. $\left({ }^{26}\right)$

No concernente a conceito, parece bastante melhor, pois escapa às observações acima, o texto do Código Civil atual: "confissão é o reconhecimento que a parte faz de um fato que lhe é desfavorável e favorece a parte contrária" (art. 352). Melhor ficaria, contudo, se não empregasse o substantivo reconhecimento, o qual poderia ser substituído com vantagem por admissão, pôsto que reconhecimento é o nomen iuris de outro instituto.

18. Segundo o Código, "diz-se documento qualquer objeto elaborado pelo homem com o fim de reproduzir ou representar uma pessoa, coisa ou fato" (art. 362), como tal se compreendendo "as reproduções fotográficas ou cinematográficas, os registos fonográficos e, de um modo geral, quaisquer outras reproduções mecânicas de fatos ou de coisas" (art. 368).

A noção é bem ampla, escapando à crítica de CUNHA GONÇALVES, endereçada à regra da lei de 1867, que restringia a definição aos documentos escritos (art. 2.420). Também ALBERTO DOS REIS, divergindo do Código, preferira conceito mais lato, preconizando o de CARNELUTTI, segundo quem, etimològicamente, documento é algo que docet, é "todo objeto material elaborado pelo homem para representar uma coisa ou um fato". $\left({ }^{27}\right)$ É manifesta a influência dessa lição na redação do Código.

Como modalidade dos documentos, aponta a lei os autênticos e os particulares (art. 363), correspondendo os primeiros aos que no direito brasileiro são considerados públicos. Trata-se de critério peculiar de classificar. MOACYR AMARAL SANTOS já anotara que "a expressão 'documentos autênticos' da técnica portuguêsa não se conforma com a conceituação de autenticidade da doutrina dominante". $\left({ }^{28}\right)$

Entre os documentos particulares a lei incluiu os telegramas, que não constavam no Código anterior, mas eram como tal considerados por CUNHA GONÇALVES com o aplauso de MOACYR AMARAL SANTOS. $\left({ }^{29}\right)$

26. J. A. DOS REIS, ob. cit., IV/7I. C. GONÇALVES, ob. cit., XIII-2/789.

27. J. A. DOS REIS, ob. cit., III/451. CARNELUTTI, Sistema, ob. cit., v. I, ps. 690/696.

28. Nota ao Tratado, de CUNHA GONÇALVES, ob. cit., XIII-2/862.

29. Tratado, ob. cit., XIII-2/998 e 1004. 
"Os documentos autênticos fazem prova plena dos fatos que referem como praticados pela autoridade ou oficial público respectivo, assim como dos fatos que nêles são atestados com base nas percepções da entidade documentadora", mas "meros juízos pessoais do documentador só valem como elementos" e ficam "sujeitos à livre apreciação do julgador" (art. 371).

Na esteira do art. 1.320 do Code Napoléon, a lei portuguêsa de 1867 continha uma regra expressa a respeito das declarações enunciativas, dizendo: "a prova que resulta dos documentos autênticos não abrange as declarações enunciativas, que se não refiram diretamente ao objeto do ato" (art. 2.427).

O Código de Processo Civil de 1939 não repetiu o dispositivo. O Prof. ALBERTO DOS REIS, após tecer algumas considerações em tôrno dessas declarações e acolhendo a lição de CARNELUTTI a seu propósito, diz que a lei processual "não reproduziu a matéria do art. 2.427 do Cód. Civil, nem fêz qualquer referência às declaraçõees enunciativas, justamente por se entender que nada havia a estabelecer, em especial, a tal respeito". $\left({ }^{30}\right)$

Realmente, o Código de Processo não reeditou as palavras do Código Civil de 1867, mas os princípios expostos no dispositivo em que tratou da "fôrça probante dos documentos autênticos" (arts. 530 na redação de 1939 e 526 na de 1961), resolvem o problema pela mesma forma. Assim opinam o próprio ALBERTO DOS REIS, sendo idêntica a nota que os Professôres PIRES DE LIMA e ANTUNES VARELA inseriram ao pé do art. 2.427 do Código Civil, em edição que anotaram e atualizaram. $\left({ }^{31}\right)$

A diretriz do Código de Processo Civil coincide com a do Código Civil atual, que não reescreveu o dispositivo de 1867, mas abrange a fôrça e efeitos das declarações enunciativas no texto acima transcrito do art. 371, segundo o qual fica livre ao juiz apreciá-las.

Os documentos particulares fazem "prova plena quanto às declarações atribuídas ao seu autor" quando apenas reconhecidos (art. 376); "se autenticados na forma notarial", entretanto, "têm a fôrça probatória dos documentos autênticos" (art. 377).

Distingue o Código entre os documentos em que a forma escrita é essencial à existência do ato jurídico ou é tão só destinada a comprová-lo. "Quando a lei exigir, como forma da declaração negocial, documento autêntico, autenticado ou particular, não pode êste ser

30. Ob. cit., III/381.

31. Coimbra Editôra Ltda., 2.a ed., 1960. 
substituído por outro meio de prova", "se, porém, resultar claramente da lei que o documento é exigido apenas para prova de declarações" já não se dá o mesmo (art. 364). Neste caso pode ser admitida como prova supletiva a confissão expressa, judicial ou extrajudicial.

Aludindo à falsidade dos documentos autênticos, o Código dá preponderância à ideológica, deixando em plano inferior a material, que poderá contudo ser declarada ex officio quando "evidente em face de sinais exteriores" (art. 372).

O Código de Processo Civil (arts. 534 na redação de 1939 e 530 na de 1961) tratava a matéria de modo mais minucioso, distinguindo a falsidade ideológica (suposição de documento; suposição de pessoas nêle mencionadas como partes ou testemunhas; menção de ter sido verificado no ato da celebração fato que realmente não se deu), da falsidade material (viciação do contexto, data ou assinatura do documentos).

O silêncio do Código Civil, porém, em nada prejudica a validade dos princípios que expunha a lei processual e a solução dos casos de falsidade terá de dar-se à luz de tais ensinamentos.

Desaparecem, isto sim, as divergências doutrinárias e jurisprudenciais $\left({ }^{32}\right)$ que a inclusão dêsses conceitos acarretava.

19. Em seguida o Código aborda dois temas que parecem desmentir tôdas as teses favoráveis à inclusão de matéria probatória em lei não-processual: prova pericial e prova por inspeção judicial. Estas se exaurem no campo processual, nenhuma razão havendo para incluí-las no Código Civil. Em abono do assêrto pode ser invocada a existência mesma de dois únicos dispositivos legais para cada qual, ao contrário da exuberância das normas alusivas a outros meios de prova.

No primeiro artigo de cada uma das duas secções cogita a lei daquilo a que chama o seu objeto.

Sôbre o primeiro lê-se isto: "a prova pericial tem por fim a percepção ou apreciação de fatos por meio de peritos, quando sejam necessários conhecimentos especiais que os julgadores não possuem, ou quando os fatos, relativos a pessoas, não devam ser objeto de inspeção judicial" (art. 388).

No outro está dito que "a prova por inspeção judicial tem por fim a percepção direta de fatos pelo tribunal" (art. 390).

32. J. A. DOS REIS, ob. cit., III/391 e segs. 
Em ambos êsses dispositivos, porém, cuida a lei ùnicamente da finalidade dos dois meios de prova, como se lê no texto: têm por fim.

A finalidade da prova é denominada função no art. 341: "as provas têm por função a demonstração da realidade dos fatos".

O descompasso vai mais longe quando se contrasta com as da lei civil as rubricas do Código de Processo Civil de 1967.

Ao regular o tema que segundo a lei civil constitui o objeto da prova, a lei de processo denomina à mesma matéria noção. Ao enfrentar igual assunto no que tange à inspeção judicial, o legislador intitula-o fim da inspeção.

Dessa confusão de rubricas resulta que no Direito Português noção, objeto e fim dos meios de prova significam uma só e mesma coisa.

É evidente o êrro, a clamar por correção.

No outro dispositivo de cada qual das duas secções (arts. 389 e 391), o Código alude à fôrça probante dessas provas, assinalando que será livremente apreciada pelo órgão julgador.

20. A última secção contém a prova testemunhal.

Distanciam-se neste assunto a lei de 1867 e a atual, que leva sôbre a anterior acentuada vantagem.

A prova testemunhal é admitida sempre que não excluída (art. 392), ficando vetada desde logo, seja por fôrça de lei ou convenção das partes, nos casos em que "a declaração negocial houver de ser reduzida a escrito ou necessitar de ser provada por escrito". Afirma a lei portuguêsa no mesmo dispositivo que não será admitida "prova por testemunhas quando o fato estiver plenamente provado por documento ou por outro meio com fôrça probatória plena", o que nem só parece um tanto óbvio como não se constitui em caso de sua inadmissibilidade, como consta da rubrica do art. 393, mas de desnecessidade. Permitida ela será, porém, para a "simples interpretação do contexto do documento".

A igual do que já dizia a lei de 1867 (art. 2.507), o Código não consente na prova por meio de testemunhas em contrário ou além do conteúdo de documentos autênticos, sejam públicos, sejam particulares regularmente autenticados. Essa regra comporta exceções, uma das quais em favor de terceiros (arts. 394, 3 e 395 in fine), outra em relação às declarações enunciativas, que já se viu não go- 
zarem da mesma proteção dispensada ao conteúdo dos documentos, podendo ser alvo de prova em contrário (art. 371). $\left({ }^{33}\right)$

Ficam, porém, expressamente sujeitos ao rigor da proibição o "acôrdo simulatório e o negócio dissimulado, quando invocados pelos simuladores" (art. 394, 2), "o cumprimento, remissão, novação, compensação e, de um modo geral, os contratos extintivos da relação obrigacional" (art. 395).

Ao contrário de várias leis, inclusive a brasileira, não figura no Código português um limite monetário à admissibilidade da prova testemunhal.

Em face da sua fôrça probante diz a lei que a prova testemunhal terá o valor que o juiz, apreciando-a livremente, Ihe atribuir (art. 396).

33. J. A. DOS REIS, ob. cit., IV/318. 